\title{
Experimental Test of Tire Cooling Equipment Using Air Devotion Method To Reduce Tire Weight Rate In Engkel Trucks
}

\author{
I Wayan Suastawa ${ }^{1}$ \\ Department of Mechanical Engineering \\ Politeknik Negeri Bali, \\ Denpasar Bali \\ 1asta782002@yahoo.com
}

\author{
Ida Bagus Putu Sukadana ${ }^{2}$ \\ Department of Mechanical Engineering \\ Politeknik Negeri Bali \\ Denpasar Bali \\ 22grantangs@ymail.com
}

\begin{abstract}
Components in the field of transportation that greatly affect the amount of transportation costs are fuel, tires and maintenance costs. On average, a tire used by commercial vehicles such as a truck, must replace all of six tires every 3 months, with a cost of approximately 1.5 to 2 million rupiah on every tire. As an academic, the author tries to study this problem by making tools to reduce tire wear rates so that later it can have an impact on reducing transportation costs. The method used is an experimental test directly on objects with treatment according to the use in the field. The temperature that causes the weakening of the tire is kept below 50 degrees celcius with a cooling device with the method of expanding air to release tire heat due to pressure and friction. The tire cooling device that has been made is attached to the left tire of an engkle truck which then operates as usual carrying sand material from the Sebudi Karangasem area to the sand dump in the Jimbaran area. Every 2 day a tire wear measurement is performed both on the left tire that gets cooling and on the right tire that does not get cooling. Furthermore, the wear rate data on the left and right tires are compared to obtain the difference in tire wear rate that gets cooling and which does not. From the data obtained, the results show that the cooling rate of tires that get cooling treatment tends to be 5,3 percent slower than the rate of tire wear that does not get the rate of cooling. From this figure it can be concluded that the use of refrigeration devices is less effective in reducing the wear rate so that other methods are needed to reduce the rate of wear.
\end{abstract}

Keywords - tire cooling, wear rate

\section{INTRODUCTION}

In vehicles transporting goods or material dimensions of vehicles and tires, it limits the transport capacity of a vehicle so that its ability is often at stake so that the economic value of the vehicle's carrying capacity becomes feasible. For example, a medium-sized truck carrying sand that has a 2 -axis vehicle dimension which should carry sand weighs 5 tons, with an economic calculation, it is used to transport sand weighing approximately 12 tons. This is what causes rapid damage to vehicle components, especially tires or the occurrence of tire rupture on the way. Based on experience passed on from generation to generation, truck drivers try to overcome and anticipate tire rupture and rapid tire wear by stopping on the side of the road to reduce tire temperature known as "Ngeban". If the tire temperature is cold enough, then the truck drivers continue the journey.
Theoretically, the damage or rupture of the tire is due to the amount of air pressure inside the tire due to various types of forces that rely on the air trapped in the tire[5],[6]. Pressure and force that rests on the air trapped in the tire increases the pressure on the tire in all directions equally. Excessive pressure or style does not necessarily cause a tire break even though it has been pressurized above the tire specification capability. However, due to lateral and longitudinal forces when moving or rotating, the pressure on the tire changes and causes temperature changes. These pressure changes accumulate and are directly proportional to the length of rotation or movement of the tire without stopping, the accumulation causes heat or changes in temperature in the air in the tire, which then moves on the rubber layer of the tire. This heat damages the tire, causing tire wear and rupture. The increase in tire temperature in addition to the rise and fall of air pressure in the tire is actually also due to the friction of the tire with the road during acceleration and braking. The only way to cool the tire back is to stop on the side of the road or silence it until the tire temperature cools back. This temperature increase is also suspected as a trigger for rapid wear of compound or palm tires. The above causes time inefficiency and increased costs. For this reason, it is important to conduct studies that can prove this empirically so that certain engineering can be done to overcome this.

From the research carried out in the first year it has been proven that a temperature of approximately 50 degrees Celsius is the point where the tensile force and the stretching force of the tire begin to weaken [3]. So if we want a tire that has the ability to remain good and able to withstand the rate of wear, which is the rate of erosion of the tire compound attached to the road surface, then we need to keep the tire temperature at a maximum of 50 degrees Celsius. So that the wear rate can be detained or reduced. In order to withstand the increase in tire temperature, a product or cooling device is designed with wind gusts from a blowing system with a certain capacity which is expected to be able to withstand the rate of tire temperature increase during operation.

In this of research, in addition to designing and constructing a prototype product, a tire cooling device will also be tested against the device whether it is effective or not in resisting the wear rate. This wear rate is actually a compound reduction rate or tire tread due to loss when 
rubbing against the road surface. The compound due to rubbing causes an increase in temperature and this increase in temperature causes the compound to become melted and sticky and stick to the surface of the road, this is what causes a mass reduction and reduction in tire dimensions.

In testing the product, field testing will be carried out by installing a product that has been built on an ankle truck on the rear tire on the right side first for data retrieval first and then on the left for subsequent data retrieval. The vehicle is operated as usual to transport material in the form of sand from the sand excavation area in the Karangasem area or from the Kelungkung area to the sand dumping area in Jimbaran hill. The test will be carried out with a duration of 3 months with dimensional measurements namely the dimensions of the tire diameter, the thickness of the palm and the width of the tire. Measurements are carried out every 7 days (1 week) by first adjusting the tire pressure so that it is always the same for each measurement. As a comparison, it is also measured the right tire without the cooling device to find out whether there is an influence of the use of the tools that have been made and how big the influence is.

If tere is a large enough influence, this cooling system can be considered effective and will be recommended for use in transport vehicles so that in general it can have a broad effect on reducing the amount of transportation costs which are already known to the tire which is the most influential component in transportation costs in addition to fuel. The bigger goal of this study is that it is expected that by reducing transportation costs, it is generally expected to reduce the price of community needs so that it will have a positive impact on the economy.

Based on the background above, then the formulation of the problem is as follows:

1. What are the results of the design of the tire cooling product on the truck?

2. What is the result of testing the tire cooling product on the truck in reducing the tire wear rate?

\section{RESEARCH METHODS}

There are several steps taken to answer the set of issues that have been determined, among others:

\section{A. Preliminary survey.}

In the initial phase, a field survey must be carried out to find out the heating load and the rate of heating that will be overcome by the cooling system to be made. This survey was carried out by recording the temperature of the tire with an infrared thermometer when operating by measuring the tire temperature every 2 hours when the tire was used on an ankle truck that was carrying material as usual when the engkle truck was operating daily. The choice of time and weather is also a benchmark for getting maximum tire temperature when operating.

\section{B. Blowing Simulation Stage}

The cooling method used to cool tires is very limited due to the microstructure of a tire that is very susceptible to water [1],[2]. The presence of moisture in the tire weakens the tire's ability to operate. This was obtained from interviews in research in the first year where vehicle operators would avoid operating during the rainy season so that they would always avoid if possible to step on puddles when it rained. Therefore the cooling method is only possible by blowing the air around or damaging the air that has been cooled beforehand with the limitation of the absence of the water molecules involved which will weaken the tire structure.

With the blowing method of course we are also required to find the right wind flow or wind gust rate so as to be able to maintain the tire temperature to remain below $70^{\circ} \mathrm{C}$. To get the rate of blowing, a simulation test is needed as shown in the following figure:

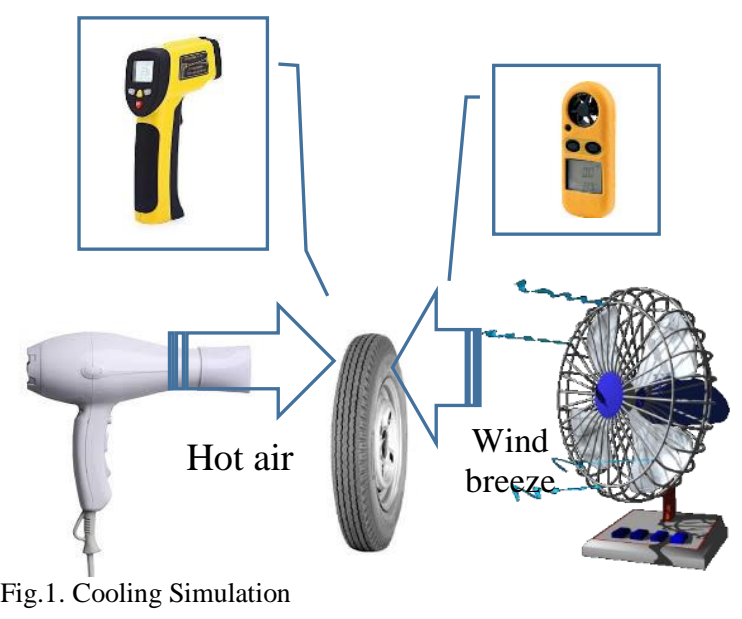

In the simulation hairdrayer is used as a heat source which in actual event is heat which is caused by wind pressure inside the tire and heat due to friction with the road. Then the hairdrayer is set to produce heat in accordance with the highest heat obtained when conducting a preliminary survey at the previous stage. With this temperature the hairdrayer funnel will be directed to the inside of the tire wall specimen that has been cut to a size of $10 \times 25 \mathrm{~cm}$. Representing a cooling device is used a fan that has 4 or more rotation variations. From all variations of the fan rotation, a variation is made to maintain the tire temperature, which does not continue to increase by more than $50^{\circ} \mathrm{C}$. An anemometer and tire temperature gauge are used as an infrared thermometer. The results of simulation testing are included in table. From the simulation test will get the right wind blowing speed that is able to maintain the tire temperature so as not to continue to increase.

\section{Design Stage}

Based on the results of the blowing simulation phase, the gust velocity will be obtained which is then selected for the type of fan, type of blade and rotation speed that is capable of producing the desired blowing. After obtaining the appropriate fan / fan and in the market, a purchase is made.

The existence of a fan that is bought into a benchmark determines the shape and dimensions other than the tire dimension of the truck itself. Sketch images that allow 
adjusting to the fan dimensions and also the dimensions of the truck's tire dimensions are as follows:

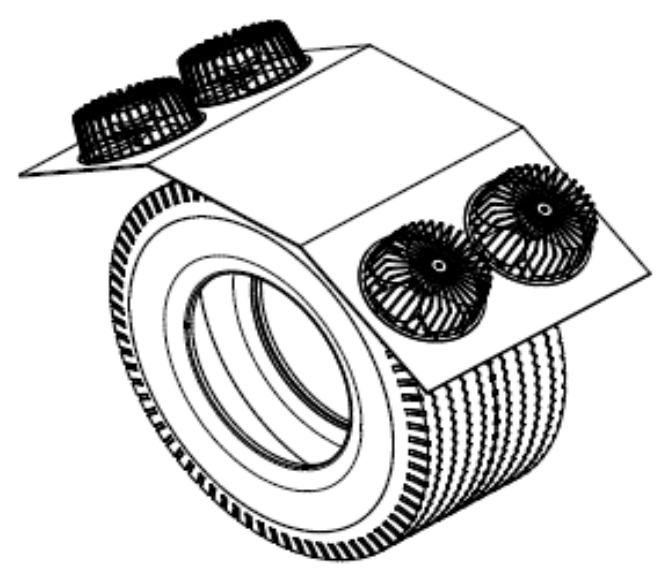

Fig.2. Design of tire cooling machine products

\section{Work drawing phase}

At this stage the work drawings will be made which will then be used as a benchmark to build the product to be made. It is planned that the product will be made on its own with the help of 2 welders. And it is carried out in a welding workshop whose location is close to the author's residence.

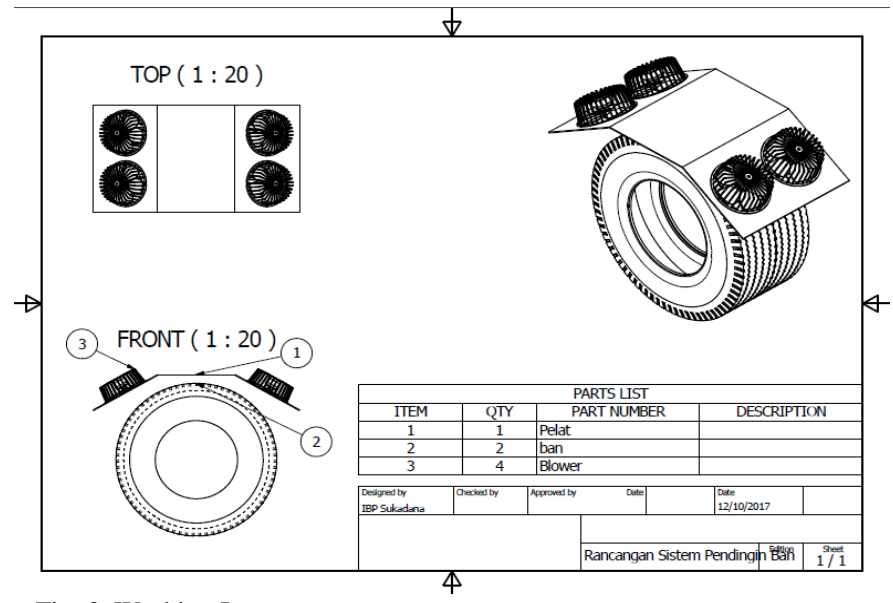

Fig. 3. Working Images

\section{E. Purchasing stage of tools and materials}

At this stage the purchase of tools and materials will be made which will become materials and components in the manufacture and assembly of products. Materials and tools include:
1. Hairdrayer
10. Welding wire
2. Standing fans
11. Hand Grinding
3. Infrared thermometer
4. digital tachometer
12. Grinding eye
5. Iron plate
13. Iron paint
6. Elbow iron
14. Thinner
7. Iron Strip
15. Extra fan
16. Bolts

8. CNP iron

9. Welding machine

17. Tire Pressure Gauge

18. Anemometer

\section{F. Workmanship (Tool Making)}

At this stage the construction of the equipment is carried out with the help of 2 assistants with the stages:

1 Reading of work drawings.

2 Making malls from cardboard

3 Eraser Plates

4 Plate bending

5 Welding

6 Cutting and welding of reinforcement frames

7 Making fan holes and fan bolt holes

8 Pinishiang and smoothing

9 Painting the base paint

10 Putting rough parts

11 Overall 2-layer painting

12 Drying

13 Fan / assembly installations

14 Cabling

\section{G. Product Testing}

At the product testing stage the following stages are carried out:

1. Installation of 4 new tires on the right side and left side

2. Installation of tire cooling products on the ankle truck on the left side rear wheel.

3. Making a schedule for measuring the thickness of the tire grip every 2 days in the truck garage on the left tire wheel that gets the cooling system and the right side that does not get cooling.

4. Grip measurement is done on 1 side with each side 3 measurement points, namely the center of the right edge and the left edge. (Figure 4)

5. Data of measurement results are written in table 4.4

6. After 1 month there will be 15 data sets on the tire on the right and left.

7. After 1 month, the data retrieval is carried out, starting with replacing the 4 tires with new tires and moving the tire cooling product to the right side.

8. Furthermore, data collection was carried out for one month by filling in

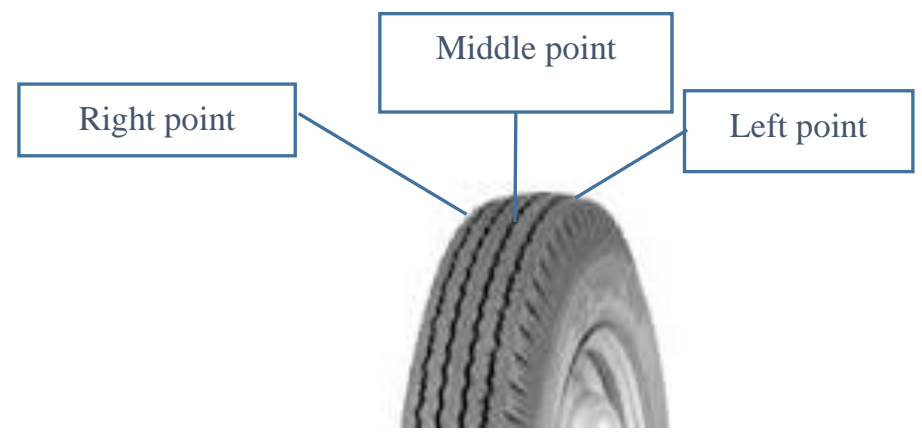

Fig. 4. Three data retrieval points on one side 


\section{H. Analysis Method}

To get a conclusion, an analysis of the data obtained from the thickness of the tire grip data will be carried out, both on the back and left side of the right side. The data set of the left tire and right tire is then averaged for the right grip, middle and left. Furthermore, it is also made on average for the right tire and the left tire that gets cooled and the right tire that does not get cooling. The average results are then made in graphical form and a description of the graph is obtained to answer the effect of the product being tested against the wear rate that occurs, which is compared with the tire wear rate chart that does not get cooling.

\section{RESULTS AND DISCUSSION}

In accordance with the above research methods, the following stages of research activities are carried out:

\section{A Preliminary survey.}

The preliminary survey was carried out by first setting a schedule to explain how to collect data from the surveyor and making a survey form. This field survey was conducted to determine the heating load and the rate of heating that will be overcome by the cooling system made. This survey was carried out by recording the temperature of the tire with an infrared thermometer when operating by measuring the tire temperature every 2 hours when the tire was used on an ankle truck that was carrying material as usual when the ankle truck was operating daily. The choice of time and weather is also a benchmark for obtaining maximum tire temperature when operating. After all preparations have been made, the survey was conducted on 23.24,25 March 2018 with the number of data per day is 5 data taken from 6 am when departing from the truck warehouse in Jimbaran until late afternoon when returning to the warehouse, with data collection every 2 hours.

TABLE I TIRE TEMPERATURE DATA WHEN OPERATED

\begin{tabular}{|c|c|c|c|l|l|}
\hline No & Date & Time & $\begin{array}{c}\text { Tire } \\
\text { Temperatur } \\
\left({ }^{\circ} \mathrm{C}\right)\end{array}$ & Weather & $\begin{array}{l}\text { Vehicle } \\
\text { load }\end{array}$ \\
\hline \hline 1 & 23-Mar-18 & 06.47 & 27,1 & cloudy & empty \\
\hline 2 & 23-Mar-18 & 09.07 & 43,6 & bright & empty \\
\hline 3 & 23-Mar-18 & 11.03 & 57,9 & bright & full \\
\hline 4 & 23-Mar-18 & 13.09 & 66,4 & bright & full \\
\hline 5 & 23-Mar-18 & 15.07 & 66,1 & bright & full \\
\hline
\end{tabular}

\begin{tabular}{|c|c|c|c|l|l|}
\hline No & Date & Time & $\begin{array}{c}\text { Tire } \\
\text { Temperature } \\
\left({ }^{\circ} \mathrm{C}\right)\end{array}$ & Weather & $\begin{array}{l}\text { Vehicle } \\
\text { load }\end{array}$ \\
\hline \hline 1 & 24-Mar-18 & 06.00 & 25,4 & bright & empty \\
\hline 2 & 24-Mar-18 & 09.11 & 40,6 & bright & empty \\
\hline 3 & 24-Mar-18 & 11.09 & 59 & bright & full \\
\hline 4 & 24-Mar-18 & 13.02 & 63,9 & bright & full \\
\hline 5 & 24-Mar-18 & 15.03 & 64,4 & bright & full \\
\hline
\end{tabular}

\begin{tabular}{|c|c|c|c|l|l|}
\hline No & Date & Time & $\begin{array}{c}\text { Tire } \\
\text { Temperature } \\
\left({ }^{\circ} \mathrm{C}\right)\end{array}$ & Weather & $\begin{array}{l}\text { Vehicle } \\
\text { load }\end{array}$ \\
\hline \hline 1 & 25-Mar-18 & 06.01 & 25,2 & bright & empty \\
\hline 2 & 25-Mar-18 & 09.01 & 46,2 & bright & empty \\
\hline 3 & 25-Mar-18 & 11.07 & 49,8 & bright & full \\
\hline 4 & 25-Mar-18 & 13.01 & 62,3 & bright & full \\
\hline 5 & 25-Mar-18 & 15.08 & 42,7 & bright & full \\
\hline
\end{tabular}

From the table, the highest tire temperature is 64.4 degrees Celsius, this temperature occurs during the afternoon before the afternoon and when the truck is carrying the cargo in full condition. From this survey it can be concluded that the weight of the load is the thing that greatly affects the increase in tire temperature when operating. From the survey data it can also be seen that around 40 percent of the temperature when operating transports material is above 50 and it is indicated that the temperature above 50 is the trigger for the high wear that occurs in the tire (Suastawa Analysis Of The Effect Of Temperature On Tire's Durability On Truck Truck Vehicle.2017)

\section{B. Blowing Simulation Stage}

In this simulation hairdrayer is used as a heat source which in actual event is heat which is caused by wind pressure inside the tire and heat due to friction with the road. Then the hairdrayer is set to produce heat in accordance with the highest heat obtained when conducting a preliminary survey at the previous stage. With this temperature the hairdrayer funnel will be directed to the inside of the tire wall specimen that has been cut to a size of $10 \times 25 \mathrm{~cm}$. Representing a cooling device is a fan that has 4 rotation variations. From all variations of the fan rotation, a variation is found which is able to maintain the tire temperature does not continue to increase more than $50^{\circ} \mathrm{C}$. Anemometer and tire temperature gauge are used as an infrared thermometer. The results of simulation testing are included in table 2. From the simulation test will get the right wind blowing speed that is able to maintain the tire temperature so as not to continue to increase.

TABLE II COOLING SIMULATION RESULTS DATA

\begin{tabular}{|c|c|c|c|c|l|}
\hline No & $\begin{array}{c}\text { wind } \\
\text { breeze } \\
(\mathrm{m} / \mathrm{s})\end{array}$ & $\begin{array}{c}\text { Time } \\
(\text { secon })\end{array}$ & $\begin{array}{c}\text { Hairdra } \\
\text { yer } \\
\text { temper } \\
\text { ature } \\
\left({ }^{\circ} \mathrm{C}\right)\end{array}$ & $\begin{array}{c}\text { Tire } \\
\text { temper } \\
\text { ature } \\
\left({ }^{\circ} \mathrm{C}\right)\end{array}$ & Information \\
\hline \hline 1 & 3,2 & 5 & 68 & 66,1 & $\begin{array}{l}\text { Tire temperature } \\
\text { increases moderately }\end{array}$ \\
\hline 2 & 4,7 & 5 & 68 & 54,3 & $\begin{array}{l}\text { tire temperature } \\
\text { increases slowly }\end{array}$ \\
\hline 3 & 5,6 & 5 & 68 & 48,3 & $\begin{array}{l}\text { tire temperature } \\
\text { increases very slowly }\end{array}$ \\
\hline 4 & 6,6 & 5 & 69 & 48,1 & $\begin{array}{l}\text { the temperature goes up } \\
\text { and down }\end{array}$ \\
\hline
\end{tabular}

From table 2, it can be seen that the air gusts from the four rotation variations that exist on the fan that is guided are obtained the velocity of the 3rd and 4th, namely with blowing 
velocity of $5.6 \mathrm{~m} / \mathrm{s}$ up to $6.6 \mathrm{~m} / \mathrm{s}$ able to maintain tire temperature who get heating inside and out of the hairdrayer.

\section{Workmanship (Tool Making)}

At this stage the construction of the equipment is carried out with the help of 2 assistants with the stages:

1. Reading of work drawings.

2. Making malls from cardboard

3. Eraser plate cutting

4. Plate bending

5. Welding

6. Cutting and welding reinforcement frames

7. Making fan holes and fan bolt holes

8. Pinishiang and smoothing

9. Painting the base paint

10. Putting rough parts

11. The entire 2-layer painting

12. Drying

13. Fan installation / assembly

14. Cabling
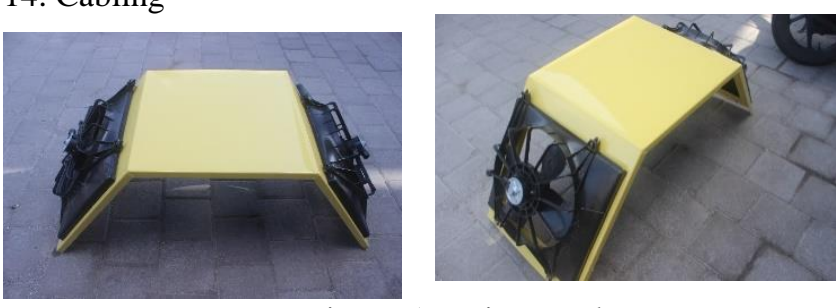

Figure 5 Design results

\section{Product Testing}

At the product testing stage the following stages are carried out:

1. Installation of 4 new tires on the right side and left side

2. Installation of tire cooling products on the ankle truck on the left side rear wheel.

3. Making a schedule for measuring the thickness of the tire grip every 2 days in the truck garage on the left tire wheel that gets a cooling system and the right side that does not get cooling.

4. Grip measurement is done on 1 side with each side carried out 3 measurement points, namely the middle of the right edge and the left edge.

5. The measurement results data are written in table $3 / 4$

6. After 1 month there will be 15 data sets on the tire on the right and left.

7. After 1 month, the data retrieval is carried out which starts with replacing the 4 tires with new tires and moving the tire cooling product to the right side.

8. Furthermore, data retrieval is carried out for one month by filling in table 3
TABLE III THICKNESS DATA ON TIRE GRIPS WITH COOLING PRODUCTS ARE MOUNTED ON THE RIGHT WITH THREE POINTS ON ONE SIDE.

\begin{tabular}{|c|c|c|c|c|c|c|c|}
\hline \multirow[t]{2}{*}{ No } & \multirow[t]{2}{*}{ Date } & \multicolumn{3}{|c|}{$\begin{array}{l}\text { Right Wheel Grip Thickness } \\
\text { that gets a cooling system } \\
(\mathrm{mm})\end{array}$} & \multicolumn{3}{|c|}{$\begin{array}{l}\text { Thickness Grip the left wheel } \\
\text { that does not get cooling } \\
(\mathrm{mm})\end{array}$} \\
\hline & & left & middle & right & left & middle & right \\
\hline 1 & 25 June 2018 & 15 & 16 & 15 & 15 & 16 & 15 \\
\hline 2 & 27 June 2018 & 15 & 16 & 15 & 15 & 16 & 15 \\
\hline 3 & 29 June 2018 & 15 & 15,5 & 15 & 14,5 & 15,5 & 15 \\
\hline 4 & 1 July 2018 & 15 & 15,5 & 15 & 14,5 & 15 & 15 \\
\hline 5 & 3 July 2018 & 15 & 15 & 15 & 14 & 15 & 15 \\
\hline 6 & 5 July 2018 & 14,5 & 15 & 15 & 14 & 13,5 & 14,5 \\
\hline 7 & 7 July 2018 & 14,5 & 14,5 & 14,5 & 13 & 14,5 & 14,5 \\
\hline 8 & 9 July 2018 & 14 & 14 & 14 & 12,5 & 12,5 & 13 \\
\hline 9 & 11 July 2018 & 13,5 & 14 & 14 & 12 & 12 & 12 \\
\hline 10 & 13 July 2018 & 13,5 & 13,5 & 13,5 & 12 & 12 & 12 \\
\hline 11 & 15 July 2018 & 12,5 & 13 & 13 & 11,5 & 12 & 12 \\
\hline 12 & 17 July 2018 & 12 & 12 & 12 & 11 & 12 & 12 \\
\hline 13 & 19 July 2018 & 11 & 11 & 11 & 10,5 & 11 & 11 \\
\hline 14 & 21 July 2018 & 10,5 & 10,5 & 11 & 10 & 10 & 10 \\
\hline 15 & 23 july 2018 & 10 & 10,5 & 10,5 & 10 & 10 & 10 \\
\hline
\end{tabular}

TABLE IV. THE THICKNESS DATA OF THE TIRE GRIPT WITH THE COOLING PRODUCT IS ATTACHED TO THE

\section{LEFT}

\begin{tabular}{|c|c|c|c|c|c|c|c|}
\hline \multirow{2}{*}{ No } & \multirow{2}{*}{ Tanggal } & \multicolumn{3}{|c|}{$\begin{array}{c}\text { Grip Thickness Left wheel } \\
\text { that gets a cooling system }\end{array}$} & \multicolumn{3}{|c|}{$\begin{array}{c}\text { Thickness Right-hand grip } \\
\text { that does not get cooling } \\
\text { (mm) }\end{array}$} \\
\cline { 3 - 8 } & & left & middle & right & left & middle & right \\
\hline \hline 1 & 26 July 2018 & 15 & 16 & 15 & 15 & 16 & 15 \\
\hline 2 & 28 July 2018 & 15 & 16 & 15 & 15 & 16 & 15 \\
\hline 3 & 30 July 2018 & 15 & 15,5 & 15 & 14,5 & 15,5 & 15 \\
\hline 4 & 1 Agst 2018 & 15 & 15,5 & 15 & 14,5 & 15 & 14,5 \\
\hline 5 & 3 Agst 2018 & 15 & 15 & 15 & 14 & 15 & 14,5 \\
\hline 6 & 5 Agst 2018 & 14,5 & 15 & 14,5 & 14,5 & 13,5 & 14,5 \\
\hline 7 & 7 Agst 2018 & 14,5 & 14,5 & 14,5 & 14 & 14,5 & 14 \\
\hline 8 & 9 Agst 2018 & 14 & 14,5 & 14 & 13 & 13 & 13 \\
\hline 9 & 11 Agst 2018 & 13,5 & 14 & 14 & 12 & 12,5 & 12,5 \\
\hline 10 & 13 Agst 2018 & 13,5 & 13,5 & 13,5 & 12 & 12 & 12 \\
\hline 11 & 15 Agst 2018 & 12,5 & 13 & 13 & 11,5 & 12 & 12 \\
\hline 12 & 18 Agst 2018 & 12 & 12 & 12 & 11 & 12 & 12 \\
\hline 13 & 20 Agst 2018 & 11 & 11 & 11 & 10 & 11 & 11,5 \\
\hline 14 & 23 Agst 2018 & 10,5 & 10,5 & 10,5 & 10 & 10,5 & 11 \\
\hline 15 & 25 Agst 2018 & 10 & 10,5 & 10,5 & 10 & 10 & 10 \\
\hline
\end{tabular}

\section{E. Analysis Method}

To obtain a table that shows a clear difference between the tires that are treated with cooling and tires that do not receive cooling treatment, a tabulation is made by making the average thickness of the tire on one side of the measurement so that the figures are the average thickness of the tire grip 3 points measured on one side. Then tabulation is done by calculating the average tire that is treated with cooling (both the right tire and the left tire) which is juxtaposed with tires that do not receive cooling treatment (right tire and left tire). 
TABLE V. AVERAGE TWO DATA DIFFERENCES

\begin{tabular}{|c|c|c|c|}
\hline $\begin{array}{c}\text { Data } \\
\text { retrieval }\end{array}$ & $\begin{array}{c}\text { Average thickness of } \\
\text { Wheel grip that gets a } \\
\text { cooling system } \\
(\mathrm{mm})\end{array}$ & $\begin{array}{c}\text { Average thickness of } \\
\text { wheel grips that do } \\
\text { not get a cooling } \\
\text { system } \\
(\mathrm{mm})\end{array}$ & $\begin{array}{c}\text { Average } \\
\text { difference }\end{array}$ \\
\hline \hline 1 & 15,33 & 15,33 & 0,00 \\
\hline 2 & 15,33 & 15,33 & 0,00 \\
\hline 3 & 15,17 & 15,00 & 0,17 \\
\hline 4 & 15,17 & 14,75 & 0,42 \\
\hline 5 & 15,00 & 14,58 & 0,42 \\
\hline 6 & 14,75 & 14,08 & 0,67 \\
\hline 7 & 14,50 & 14,00 & 0,50 \\
\hline 8 & 14,08 & 12,83 & 1,25 \\
\hline 9 & 13,83 & 12,42 & 1,42 \\
\hline 10 & 13,50 & 12,17 & 1,33 \\
\hline 11 & 12,83 & 11,83 & 1,00 \\
\hline 12 & 12,00 & 11,08 & 0,92 \\
\hline 13 & 11,25 & 10,42 & 0,83 \\
\hline 14 & 10,58 & 9,83 & 0,75 \\
\hline 15 & 10,33 & 9,17 & 1,17 \\
\hline $\begin{array}{c}\text { Rata- } \\
\text { rata }\end{array}$ & 13,58 & 12,86 & 0,72 \\
\hline & Difference Percentage & $5,3 \%$ \\
\cline { 2 - 4 } & & & \\
\hline
\end{tabular}

From the table, it can be seen that the average thickness of tire grips that are subjected to cooling is always greater than tires that do not receive cooling treatment. From the calculation results, the percentage difference is $5.3 \%$.

Furthermore, from the table above it is transformed into a graph to see the difference in grip thickness and wear rate.

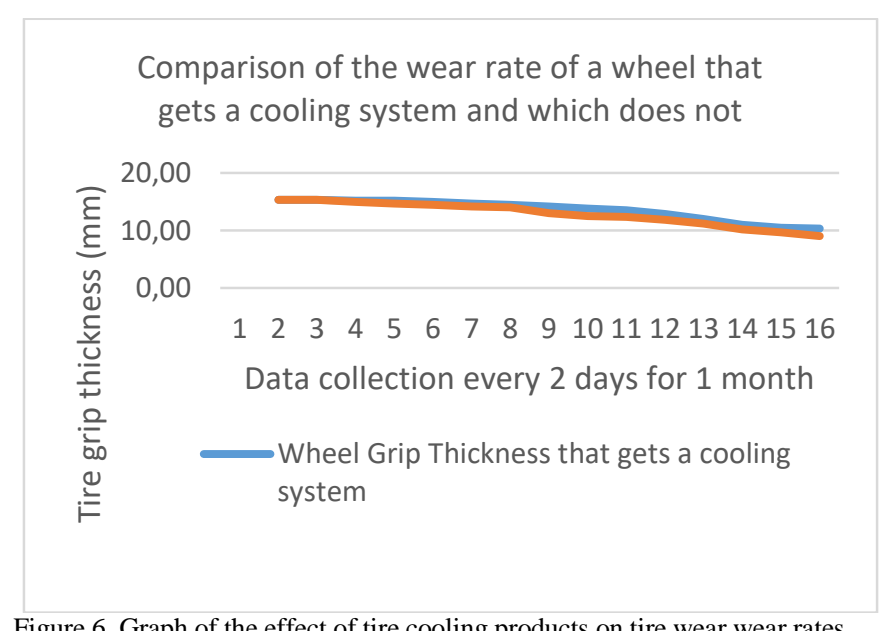

Figure 6. Graph of the effect of tire cooling products on tire wear wear rates

\section{CONCLUSIONS}

From the graph above, it can be seen that overall tires that are treated with cooling from tire cooling products have a thicker thickness of tire grip compared to tires that do not receive cooling treatment. The difference appears to be enlarged in the middle of the month when wear has reached 2 to 3 millimeters this is due to the tire compound which is getting softened on the inside of the tire while not getting a cooling process from the tire cooling product. And from the table 5 we have conclution that The tire cooling results in cooling products being able to reduce tire wear by 5.3 percent.

\section{ACKNOWLEDGMENT}

The authors would like to thank the Directorate General for Research Strengthening and Development, Ministry of Research, Technology and Higher Education, Republic of Indonesia which has funded this research

\section{REFERENCES}

[1] H.T. Sularso, Pompa dan Kompresor: Pemilihan, Pemakaian dan Pemeliharaan, Association for International Technical Promotion: Tokyo, 1983.

[2] M.S.M. E. Sularso, Dasar Perencanaan Dan Pemilihan Eleman Elemen Mesin, Pradnya Paramita: Jakarta, 2002.

[3] I.W. Suastawa and I.B. Sukadana, Analysis of The Effect of Temperature on Tire's Durability on Engkel Truck Vehicle. unpublished.

[4] P. Hari, "Arang Aktif Serbuk Gergaji Bahan Pengisi Untuk Pembuatan Kompon Ban Luar Kendaraan Bermotor,” J. Riset Industri, vol. 6, no. 2, pp. 49-57, 2012.

[5] I.H. Siahaan, N. Djonoadji, and A. Sugondo, Analisa Gaya pada Roda Kendaraan pada Berbagai Kecepatan, unpublished.

[6] M. Rahmaniar, "Pengaruh Ukuran Partikel Nano Sulfur Terhadap Sifat Fisis Karet Komponen Kendaraan Bermotor," J. Riset Industri., vol. 4, no. 1, pp. 17-24, 2010. 